\title{
WEB-GIS SOLUTIONS DEVELOPMENT FOR CITIZENS AND WATER COMPANIES
}

\author{
M. Şercăianu
}

Dept. of Urban Engineering and Regional Development, Technical University of Civil Engineering Bucharest, 122-124 Lacul Tei Ave, 020396, Romania - mihai.sercaianu@utcb.ro

KEY WORDS: citizen, municipal companies, communication, web-GIS

\begin{abstract}
:
This paper describes the development of a web-GIS solution in which urban residents, from Buzau City, could be involved in decision-support process of water companies, in order to reduce water losses, by collecting information directly from citizens. In recent years, reducing material and economic losses, recorded in the entire municipal networks management process has become the main focus of public companies in Romania. Due to problems complexity that arise in collecting information from citizens and issues identified in urban areas, more analyzes were required related to web-GIS solutions used in areas such as local government, public utilities, environmental protection or financial management. Another important problem is the poor infrastructure development of spatial databases founded in public companies, and connection to web platforms. Developing the entire communication process between residents and municipal companies has required the use of concept "citizen-sensor" in the entire reporting process. Reported problems are related to water distribution networks with the possibility of covering the entire public utilities infrastructure.
\end{abstract}

\section{INTRODUCTION}

\subsection{General context}

One of the main problems, identified in the Romanian's public companies is the poor information exchange between public relation departments and citizens. From here another type of problems arise, such as poor spatial databases infrastructure development and reliable connection to web solutions. One way to solve problems arising from collecting information is to adapt and improve traditional solutions of interaction with citizens identified in the public companies. In this process, public participation will be archived using "citizen-sensor" concept for reporting problems related to water distribution network, with the possibly of extending to the entire public utilities infrastructure. Based on decision makers' characteristics identified at the municipal operator and local government structure, the proposed solution will improve communication with residents, along with their involvement in decision-making process.

Some institutional aspects and components could influence the implementation of web-GIS solutions within these institutions such as: public company age, promoted values, operating procedures related to their main beneficiaries (households), willingness to acquire new knowledge and implement new solutions (both socially and technologically), characteristics and nature of their clients, promoting necessity, credibility and visibility.

In terms of implementing new solutions to public companies we can identify some particular risks: citizens interest, or indifference in some cases; requested time period for its implementation; higher or lower implementation costs; any disruption in organization's operation; organization discredit in case of incorrect solution implementation in terms of "public company image". In the same time it must be borne in mind that the main beneficiary of water supply and sewerage is the citizen, who in addition to regular use of services, wants at different period of time certain problems to be solved and certain services to be improved (Figure 1.).

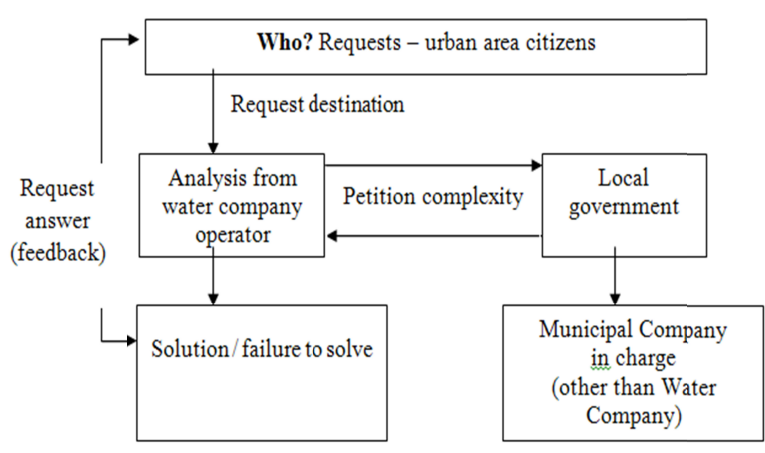

Figure 1. Identified directions for solving problems requested by the citizens

\subsection{Public companies selection}

Given the range of services offered to citizens and the type of communication adopted were analyzed in detail: two water and sewerage companies (S.C. Apa Nova Bucureşti S.A. bidirectional communication, and S.C. Compania de Apa S.A. Buzău - bidirectional communication), one heat distribution autonomous company (Regia Autonoma de Distribuție a Energiei Termice Bucureşti - unidirectional communication), one electrical distribution company (Enel Muntenia bidirectional communication) and one urban public transport service, (Regia Autonomă de Transport Bucureşti bidirectional communication). Communication between utility companies and citizens is achieved by two main ways: unidirectional and bidirectional (Figure 2.). In unidirectional communications, the company is offering / imposing for citizen's attention different information on service provided 
tariffs and way of payments, etc. Citizen only choice is to accept an agreement for providing services by the operator, or to refuse it due to commercial monopole of some companies. A bidirectional communication allows also a feedback from citizens on payment services, questions and suggestions to improve the service provided, interactivity offered by certain web portals by the company through digital maps usage.

The challenge lies in providing information and community involvement in a clear and significant way due to problems complexity. Location request on a particular service offers the development trend of a city area parallel to the accurate positioning.

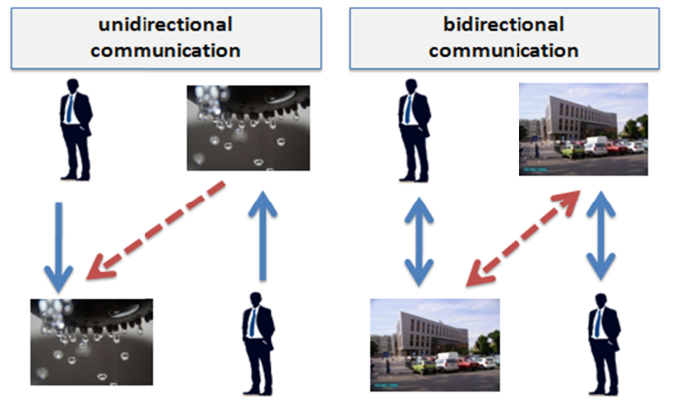

Figure 2. Main ways of communication: between citizens and municipal companies

Before designing and using an application using GIS technology in necessary to express in a more coherent manner the ultimate goal of the project, which is the financial and logistical implications of customers, respectively the type of application that is compatible. Also should be defined exactly which data sets can be interpreted, processed or replaced by the user. Whether we discuss an application designed for urban planning, management services or public awareness the conditions and development trends of GIS solutions should be followed in real time

\section{BUZAU CITY WEB-GIS APLICATION}

\subsection{Buzau City Characteristics}

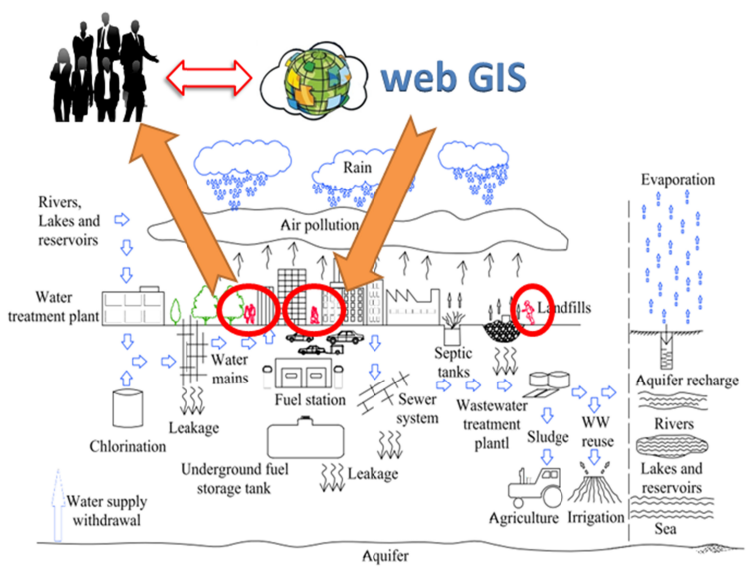

Figure.3. Urban water cycle (Adapted from: McPherson, 1973; McPherson and Schneider,1973) and foreword to "citizensensor" concept)
During the operation of water distribution network, process parameters and equipment status are monitored and recorded using different sensors or measuring devices located on-site.

Urban areas have as main characteristic density housing function, respectively population density that reside in that area, and a set of required urban services such as public transport or urban utility network. At the local level among all urban services is a high level of interaction because they operate in a limited space as shown in figure.3. Information, expressing satisfaction or dissatisfaction of the population on the entire water distribution service, are collected in a low and in some cases is missing. This requires the use of concept "citizensensor" that can transmit in real-time the information to operator using interactive web-GIS platforms.

\subsection{Designing "Citizen-Sensor" Buzau Application}

\subsubsection{Geodatabase Structure}

Because it was necessary to analyze an urban area with sufficient information offered by public institutions, with the possibility of performing various analyzes, we chose a study area of $3.4 \mathrm{~km}^{2}$ in Buzău City. As a general concept, spatial database contains both high-density data located in Buzău strictly urban area, and buffer information of adjacent elements.

The geodatabase and application represents the support of information management that came from citizens, offering the necessary tools in processing and visualizations the entire urban study area. The proposed architecture of the support database consists in seven modules structured according to their defining characteristics (Table 1). For the study to be as conclusive in terms of future visual identity made by citizens in the web platform, the database was designed with accuracy as high as possible.

\begin{tabular}{|c|c|c|}
\hline No & Module & Description \\
\hline 1 & $\begin{array}{l}\text { Urban } \\
\text { component }\end{array}$ & $\begin{array}{l}\text { Describe the urban structure ge- } \\
\text { ometry such as street network, } \\
\text { parcels, buildings, green spaces, } \\
\text { etc. }\end{array}$ \\
\hline 3 & $\begin{array}{l}\text { Urban structure } \\
\text { characteristics }\end{array}$ & $\begin{array}{l}\text { Contains punctual, linear, or buff- } \\
\text { er information related to events } \\
\text { that are taking place in the area }\end{array}$ \\
\hline 4. & Water network & $\begin{array}{l}\text { Describe geometric elements like } \\
\text { water network pipelines, nodes, } \\
\text { manholes, branching points, hy- } \\
\text { drants, etc. }\end{array}$ \\
\hline 5. & $\begin{array}{l}\text { Water network } \\
\text { characteristics }\end{array}$ & $\begin{array}{l}\text { Contains punctual, linear, or buff- } \\
\text { er information related to water } \\
\text { network operation. }\end{array}$ \\
\hline 6. & $\begin{array}{l}\text { Citizens } \\
\text { requests }\end{array}$ & $\begin{array}{l}\text { Contains punctual and descriptive } \\
\text { information related to citizens re- } \\
\text { quests }\end{array}$ \\
\hline 7 & $\begin{array}{l}\text { Operator } \\
\text { intervention }\end{array}$ & $\begin{array}{l}\text { Contains punctual and descriptive } \\
\text { information related to operator in- } \\
\text { terventions }\end{array}$ \\
\hline 8. & Documents & $\begin{array}{l}\text { Contains publics documents that } \\
\text { can be offered to users, such laws } \\
\text { or free cadastral plans }\end{array}$ \\
\hline
\end{tabular}

Table 1. Database architecture (MCD Modules) 
Later for the construction of water distribution network, cadastral plans from the first phase could not be used, because they did not contain enough information to be interpreted later. The new data set was based on project 2002/RO/16/P/PE/021 "Rehabilitation, extension, modernization of the drinking water distribution and sewerage networks" in Buzău City financed through ISPA Program. This data set contains network characteristics and properties in a unitary structure for a network length of $9.7 \mathrm{~km}$.

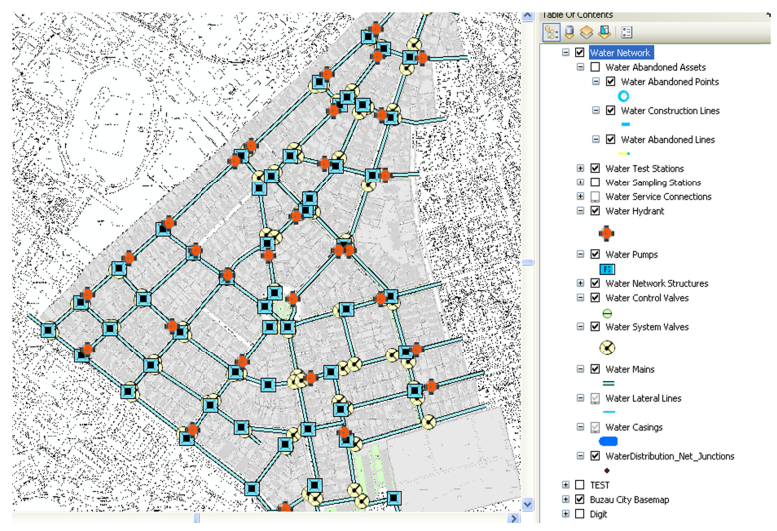

Figure 4. Water distribution network, pilot area, Buzău City;

This interactive application includes a base map built for the pilot study case and a reporting solution from the field, directly at citizen's home. Along with reporting identified problems, people can view previous requests made by other residents of the urban area. This base map provides a graphical representation of build objects and land elements that can be used to locate water mains, street network, parcels, and structures in geographical coordinates.

\subsubsection{Designing the web-GIS Application}

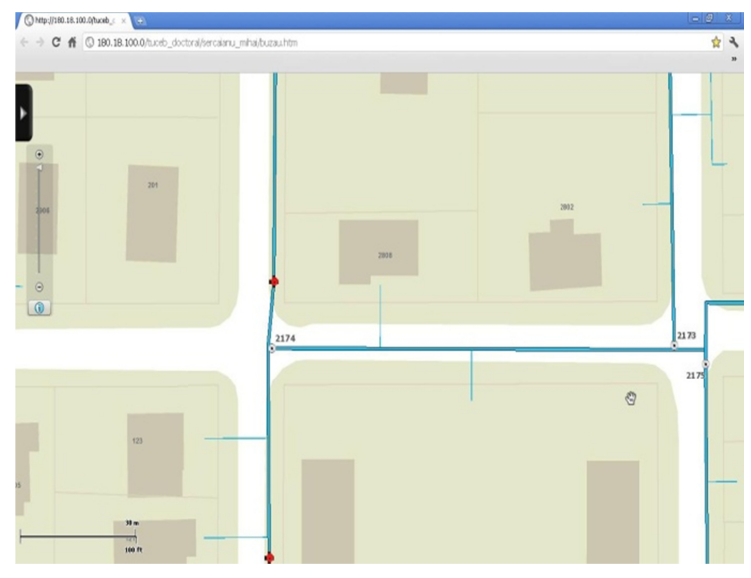

Figure 5. Web application for the study case

In the process of designing the web application, the concept of citizen-sensor was used, because some information provided by citizens will not have a technical description but will need to be take into consideration and analyzed by the company operator. Storing these types of information from citizens might lead to the proposal of new solutions directed to citizen, whether we discuss for a public policy or services improvement provided to urban residents. For publishing and viewing maps in web application, we used the ArcGIS Server 10 software. Any citizen with Internet access, who lives in the pilot study area, could easily view their own neighborhood map in order to report problems from the field, or to propose recommendations/solutions for water distribution network good operation (Figure 5).

By submitting an online request, the citizen will be able to see his own application but also the past interventions from the water company, classified into three categories (Figure 6)

- Assigned - the request is assigned at the operator level for future solution (further the citizen can complete his own request with other comments and recommendations related to his problem);

- Unassigned - the request is unassigned at the operator level and the user will not be able to post new comments until the request is assigned;

- Closed - the request was solved by the network operator in charge.

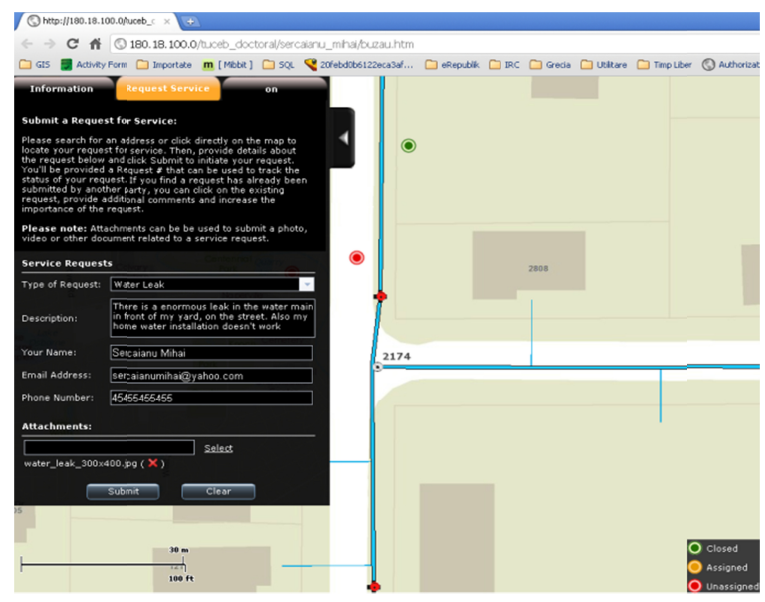

Figure 6. Citizen request solution for Buzau web-application

Based on approach classification in terms of solutions that are based on citizen involvement in collecting information (Newman, G. et al, 2011), and also reporting problems from field by them, the pilot application from Buzau City can be included in "collaborative" "contributory" and "co-developed" categories (long-term visualization, reporting, water distribution networks analysis, real-time reports and feedback, voluntary involvement), and with the possibility of extension to public or private activities sectors.

\subsection{Estimation of citizens' perception from study area}

To identify the type of beneficiaries and assess people's perception about the possibility of implementing web-GIS platform in the water company, we conducted a field study during period 02.06-09.06.2012 based on statistical approach. Questions contained in the questionnaire aimed to quantify public perceptions related to Water Company by categories: water quality provided, company services, company communication related to clients, bills collection system and ways to solve network breakdown (table 2). In addition, a set of questions were introduced to express the possibility and ways of involving citizens in the future decision process, using online solutions based conventional one. 
In terms of solution applicability at the institutional level, some issues take into account citizens' perception, for example their motivation to engage in an online environment by generating field requests. A simple presentation of the application will not automatically lead citizens to use it unconditionally. Project results prove valuable for a much wider range of users who use the internet daily, hold a high quantity of local information and are willing to communicate with responsible institution (whether we are talking about a company or public authority). Practical purpose of the application is more than to provide for citizens, located in urban areas, or for the municipal water company the opportunity to interact and to request information in case of field breakdown.

\begin{tabular}{|c|c|c|}
\hline \multicolumn{2}{|c|}{ Question: } & Answers: \\
\hline \multicolumn{3}{|c|}{ 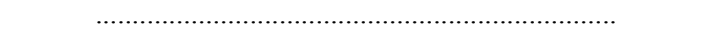 } \\
\hline \multicolumn{3}{|c|}{$\begin{array}{l}\text { 6. How do you want to get involved in the future decision } \\
\text { process? }\end{array}$} \\
\hline \multicolumn{2}{|c|}{$\begin{array}{l}\text { 1. Using classical tools such as } \\
\text { phone/fax/printed mail. }\end{array}$} & $\begin{array}{l}\text { yes } \mid \text { no } \mid \text { I can't } \\
\text { decide }\end{array}$ \\
\hline \multicolumn{2}{|c|}{$\begin{array}{l}\text { 2. Directly at the public authority head- } \\
\text { quarter thought a printed form. }\end{array}$} & $\begin{array}{l}\text { yes } \mid \text { no } \mid \text { I can't } \\
\text { decide }\end{array}$ \\
\hline \multicolumn{2}{|c|}{$\begin{array}{l}\text { 3. Using web application with online } \\
\text { forms. }\end{array}$} & $\begin{array}{l}\text { yes } \mid \text { no } \mid \text { I can’t } \\
\text { decide }\end{array}$ \\
\hline \multicolumn{2}{|c|}{$\begin{array}{l}\text { 4. Using web application, online maps } \\
\text { and graphical tools that contain street, } \\
\text { zip and cadastral number reference. }\end{array}$} & $\begin{array}{c}\text { yes } \mid \text { no } \mid \text { I can’t } \\
\text { decide }\end{array}$ \\
\hline \multicolumn{2}{|c|}{ 5. Using web-mobile application. } & $\begin{array}{l}\text { yes } \mid \text { no } \mid \text { I can’t } \\
\text { decide }\end{array}$ \\
\hline \multicolumn{3}{|l|}{ Location } \\
\hline Postal code & \multicolumn{2}{|c|}{ (n) } \\
\hline Age category?* & \multicolumn{2}{|l|}{ ( } \\
\hline
\end{tabular}

Table 2. Field questionnaire for Buzau Study Case (selection)

\section{CONCLUSIONS}

By increasing public participation in reporting problems process identified in the water distribution network, community interest will increase related to work carried out by municipal companies, where requests will be solved in short time and lower costs. If companies or local authorities will not develop solutions that improves institutional transparency the amount of information collected will be lower due to lack of public confidence. In addition to problems requested by the citizens, the application should contain technical information of general interest, for example the possible source of water losses.

New applications for citizens, implemented at the water company level, should have a similar structure and interface to applications already used by people, regardless of their internet connection speed

Analyzing municipal companies in Romania at department level can draw some important conclusions. For companies serving small and medium urban areas ITC technologies use is not a priority due to internal financial policy and monopole. For this type of company is more important the field network development or breakdown limitation. Therefore, dissatisfied citizens are forced to keep their current provider in absence of other al- ternatives. For companies serving large sized urban areas, where the citizens' mobility is high and access to ICT technologies is growing, customer relations departments have a higher degree of development. From the perspective of the customer relations department modern technologies are used to a minimum and limited to simple complaints. Prolonged or incomplete response time leads to loss of public confidence in the company. Filling out simple online forms does not automatically lead to department's development.

Visual image of the water distribution company can be improved by eliminating aspects that characterize them now, namely inefficiency and focus strictly on the financial aspect. Such image is not positive for customer relations and for the citizens generally. Timely solution implementation with lower costs will create a positive and a modern image to the main beneficiary from urban areas: the citizen. In the regionalization or reorganization context the water supply, company that worked so far only locally, must adapt to new customers requirements that include access to information more quickly.

The company must be known to customers and to update relations with other urban operators. This requires public relations campaigns and customer information adapted to local aspects. A larger company leads to increased professionalism with better service with the risk of excessive secrecy related to some public information. For a company to attract the interest of the main beneficiaries, in a possible involvement of data collection, must take place prior various information campaigns such as: customer letters, brochures, websites, media advertisements (print, audio or video), posters in public places (front desks or water company headquarters), promotion trough their personnel (own staff need to be well trained before the campaign), active and exposure at public events (fairs or water days), sponsoring local and regional events, water open days, etc.

So that the solution can work, identity of the beneficiary must be unique. Errors that may occur must be avoided due to duplication of postal codes or the use of mistaken contract numbers and names. Customer identification indicates preferably the direct geographical location of the customer, prior to other types of information. Maintaining contact with the public and with commercial beneficiaries of the service is of vital importance for Water Supply Company. This means listening and inviting citizens to make suggestions and requests measured by different indicators.

\section{FUTURE DEVELOPMENT}

This web-GIS application will inspire the local government to make applications for environmental protection, urban traffic management and local tourism development. At the same time, it represents the beginning of development similar applications in other public utilities companies. To facilitate public participation in the process of collecting information is necessary for spatial databases managed by public administration, connected to other utility operators' databases.

All services provided to citizens currently require a review and a regroup in a single contact point, in order to request municipal services and report breakdowns in the provision of these services. As described in paper's chapters, providing services to/from central dispatcher can be traditional (over the front desk or by phone) or electronically (via a web portal). 
Another element that will require attention is represented by the fact that database and all application will be secured against theft of confidential information or overloading the system with false claims. Finally it should be noted that the research is interdisciplinary and complex enabling the development of future studies according to technological developments.

\section{REFERENCES}

Arctur, D., Zeiler, M., 2004. Designing Geodatabases. Case Studies in GIS Data Modeling. ESRI Press.

Danielson, L. and White, N., 1998-2012. Using GIS in public policy analysis: North Carolina. Raleigh, N. C.: Design Research Laboratory, North Carolina State University, http://www.ces.ncsu.edu/depts/design/research/WECO/policyG IS/index.html (3 March 2012)

Gerull, L., 2005. External services în. The GIS Guide for Local Government Officials in. Ed. by Cory Fleming. International City/Country Management Association (ICMA). ESRI Press, Chapter 5, pp.81-104.

Kingstom, R. 2007. Public Participation in Local Policy Decision-making: The Role of Web-Based Mapping. The Cartographic Journal vol.44 no.2, pp.138-144.

Marsalek J., Cisneros J., Karamouz M., Malmquist P.A., Goldenfum J., Chocat B., eds. 2008 - Urban Water Cycle Processes and Interactions, UNESCO Publishing; Chapter. 1, , pp.9-18

McPherson, M.B., 1973. Need for metropolitan water balance inventories. Journal of Hydraulics Div., ASCE, Vol. 99, No.HY19, , pp.1837-1838.

McPherson, M.B., Schneider, W.J., 1974. Problems in modeling urban watersheds. Water Resources, Vol.10, No.3, pp.434440 .

Newman,G., Graham,J., Crall, A., Laituri, M., 2011. The art and science of multi-scale citizen science support. Ecological Informatics.

Petrescu, F., 2007. Geographic Informatics Systems in Urban and Regional Planning. Bucharest, ed. Matrix Rom.

Pricopie, R., 2010. Public Participation. Communications for sustainable development, (Participarea publică, Comunicare pentru dezvoltare durabilă), Ed. Comunicare.ro.

Waite, B.,2005. Planning, implementing and funding a GIS. în The GIS Guide for Local Government Officials Ed. by Cory Fleming. International City/Country Management Association (ICMA). ESRI Press, Chapter 3, pp.29-60. 